\title{
Feasibility Study on Establishment Noodle Rice Bran Stall
}

\author{
$1^{\text {st }}$ Ali Hasbi Ramadani, S.Pd, M.Pd \\ Faculty of engineering \\ State University of Hasyim Asy'ari \\ Jombang, Indonesian \\ Alihasbi89@yahoo.com
}

\author{
$2^{\text {nd }}$ Adhika May asari, S.T., M. Eng. \\ Faculty of engineering \\ State University of Hasyim Asy ari \\ Jombang, Indonesian \\ andhikamayasari@gmail.com
}

\begin{abstract}
The purpose of this study is to analyze the feasibility of the producing Chicken Noodle based on Rice brand which is have many advantages for human body. In conducting this feasibility analysis will be reviewed through 6 aspects, including market, technical and management, legal permit, environmental issue, and financial aspects.

Data collection covers on preliminary study (observation), interview, pictures documentation, and library research. Non financial analysis on this research will be on market analysis, technical issue, finance, management, law and environmental aspects presented as qualitative data which present in descriptive form. Qualitative data is the result of analysis on financial aspect using Microsoft Excel program computer and presented in tabulation form used to classify existing data and simplify in doing data analysis.

Based on the results of non-financial feasibility analysis on a market, technical, management, law and environment aspects, still not found any obstacles for the establishment of healthy rice brand Chicken Noodle, but the things have to concern is the technical aspects because the raw material for the product still imported from the outside. For the results of financial analysis in accordance with investment valuation criteria obtained Net Present Value (NPV) results of $R p .137,883,346$, Internal Rate of Return (IRR) of 45\%, Net Benefit-Cost Ratio (Net B / C) obtained 2.01, Break Even Point (BEP) of Rp. 32.911.279, and Payback Period (PP) is 1 year 7 months 6 days. In short, the establishment of Rice Brand Chicken Noodle Stall is feasible to be run and developed.
\end{abstract}

Keywords - Feasibility study; Rice Brand; Noodle Rice Brand

\section{INTRODUCTION}

In globalization era nowadays people tend to fulfill their needs by running on the entrepreneur track, which is started from small to huge chain of business. Creativity is very important to opening another possibility for any job field and to expand the existing business.

UKM plays an important role for economic development in Indonesia. The data taken from Kementrian Negara dan Koperasi, stated that UKM contributed more than $50 \%$ for the National GDP.UKM is able to absorb labors up to 85.4 million people. This fact is showed us how UKM is on strategic position in order to solve the unemployment in Indonesia. Chicken noodle is one of the UKM engaged in the culinary field that until now still exist and business actor chicken noodle is likely to increase.

Chicken Noodle is one of Indonesian food based from yellow noodle processed by boiling it on hot water then pour with soy sauce, slice of meat and vegetables. Although the origin of this cuisine is not from Indonesia, Chicken Noodle were accepted and widely known as one of Indonesian traditional food, particularly in Java.

Flour is the main ingredient for Chicken Noodle and still not any reference for the healthier one. One of suggested ingredient for a healthy Chicken Noodle is use a rice brand. Based on several research concluded that a rice brand contained high nutritional value, bioactive antioxidant, and rice brand sacharida. Antioxidant could help to prevent from diabetes, Alzheimer's disease, heart disease and cancer [1], antioxidants contains in rice brand, particularly vitamin E and Oryzanol, and unsaturated fats can reduces cholesterol, and rice brand sacharida avoiding from cancer [2] [3]. Gescher A [4] added that a daily rice brand consumption would reduces until $51 \%$ risk of adenoma cancer in the intestinal tract.

Research on Instant Noodle Formulation with some rice brand was conducted by Liandani and Zubaidah. The aim is to know the effect of rice bran toward the instant noodle related to physical, chemical, organoleptic criteria contained in Instant Noodle production. The results get increase up to $5 \%$ after mixed by rice bran.

This research will be focused on the feasibility study on the beneficial effect on chicken noodle based on rice bran. So the results of this study can be used as a benefit feedback for any entrepreneurs which concern on producing a healthy product or everyone who want to get involve to make a healthy rice bran Chicken Noodle.

Sugiharto [5] suggested to have a plan such investments for middle scale company, the owner obviously try to expand their company in accordance to meet the company's goal which mostly around on how to get a maximum profit for the company welfare. From this position, the calculated of Break Even Point for the business is become very important. So that, before the company want to start for a new business expansion, the first thing to consider is the investment is clearly save and health, and can be done in a certain period and get profit. In 
addition, this investment is aim to look forward for a good progress, instead of provide other financial benefits as expected.

The long-term goal of this study is to analyze the feasibility of rice bran chicken noodle busines s plan because of some good advantages on it. In conducting this feasibility analysis, it will be reviewed through 6 aspects, including market, technical, management, legal, environmental and financial aspect.

\section{A. Feasibility Study}

Understanding study of the business feasibility or feasibility study is a research on a project whether it can be done successfully. The term "project" means of the establishment of a new business or the introduction on a mixed of stuff and service into a new product that has been produced before. The business feasibility study is aim to assess the success of a project, to identify the all factors should be considered and integrate with analysis which are covering some factors related to technical, market and marketing aspects, financial, management, legal and project benefits to the local economy [6]. Aspects of assessment in the business feasibility study are as follows:

\section{Market and Marketing Aspects}

Kemampuan analisis pemasaran sangat penting untuk keberhasilan perusahaan. Jika suatu perusahaan dapat menjualkan produkyang sama dengan lebih banyak, dengan kualitas yang sama, dengan harga yang lebih mahal, atau dapat mengembangkan produk baru yang lebih berhasil, perusahaan tersebut relative telah berhasil menggunakan kemampuan analis is pemasarannya [7].

Evaluation of marketing parameters are included:

a. The marketing environment, such as markets, consumers, impressions, competitors, economic trends, business climate and social conditions and changes.

b. Marketing activities, such as production, set prices, distribution channels, advertising, face-to-face sales, publicity and promotion.

c. Marketing management, such as goal, organizations, controls and programs. Mixed Marketing is four main components in marketing such as::

1) Product, it can be goods or services that can be traded. In product marketing anything can be offered to a market to satisfy a desire or needs. In a retailer level, the product oftenly refers as a merchandise. In manufacturing process, products was purchased in the form of raw material and sold as a final product. Products in form of raw material such as metal or agricultural products are often referred as commodities.

2) Price is an exchange rate that can be equated with money or other goods to obtain benefits derived from a good or service for a person or group in a particular time and place.

3) Place is the spot or venue use for buying and selling activity including the distribution.

4) Promotion is to notify or offer a product or service with the aim of attracting potential consumers to buy our product.
Through promotion, a producers can figure out and expect for the increase of sales figures

\section{Aspects of Mangjement}

To evaluate management aspect will cover on two things, the first is the current management of the plant and the second is management when the factory has been operationalized. In business development, the management's study is includes of drawing up on a work plan, whose the people to get involved, how to coordinate and oversee a project implementation as well as possible. For the operational studies of the project, is to determine in effectively and efficiently way about the form of business entities, types of jobs, organizational structure and procurement for labor required.

\section{Technical Aspects}

The evaluation of these technical aspects examines the technical needs of the plant, such as the determination of production capacity, the type of technology, the use of equipment and machinery, the location of the plant and the most favorable plant location. From the conclusions it can be proposed a plan on the amount of the cost of procurement of permanent property.

\section{Financial aspect}

Evaluation conducted on this financial aspect to determine the financial impact of the project. The purpose of the project analysis is to: a) to determine the level of benefits achieved through investments in a project, b) avoid waste of resources, by avoiding unfavorable project implementation, c) appraising existing investment opportunities to choose the most profitable alternative projects, and the last d) determine investment priorities [8].

The methods generally considered in the assessment of an investment are:

\section{a. Payback Period (PP)}

PP or rate of return on investment is a method in assessing the feasibility of a business used to measure the period of payback period. The sooner the money returns, the better the project will be ready to built because the capital returns can be use for financing other activities.

$$
P B P=\frac{\text { Initial investment }}{\text { Acceptance period }} \times 1 \text { year }
$$

\section{b. Internal Rate of Return (IRR)}

IRR is the interest rate that equates the expected cash out present with the expected present value of the expected cash inflows, or is defined as the interest rate that causes the net present value (NPV) equal to zero. The IRR rate reflects the interest rate that the project can pay for the resources used. An investment is considered feasible if it has an IRR value greater than the prevailing interest rate and an investment is considered unfeasible if it has an IRR value smaller than the prevailing interest rate.

\section{c. Net Present Value (NPV)}

NPV is defined as the present value of the cash flows generated by the investments. NPV is defined as the net present 
value, the annual cash flow after tax is reduced by the initial outlay. In calculating the NPV it is necessary to determine the relevant interest rate. The criteria of an investment based on NPV are:

1) $\mathrm{NPV}=0$, it means the project is able to provide a return rate of social capital investment cost factor normal production. In other words, the project is neither profit nor loss.

2) NPV $>0$, means a project is declared to be profitable and workable.

3) NPV $<0$, means the project does not generate the value of the cost used, or the project is disadvantageous and should not be implemented.

\section{d. Benefit-Cost Ratio (B/C Ratio)}

The calculation of $\mathrm{B} / \mathrm{C}$ ratio is the ratio between total revenue and total cost, which shows the value of receipts earned from each rupiah issued. The project is declared feasible if the ratio of $\mathrm{B} / \mathrm{C} \geq 1[9]$.

$$
B / \text { Ratio }=\sum_{t=1}^{n} \frac{\left(B_{t}-C_{t}\right)}{(1+I R R)^{t}}
$$

Where : $\mathrm{B}_{\mathrm{t}}=$ gross profit $\mathrm{t}$-year

$$
\mathrm{N}=\text { Economic age }
$$$$
\mathrm{C}_{\mathrm{t}}=\text { gross year } \mathrm{t}-\mathrm{year}
$$

\section{e. Break Event Point (BEP)}

BEP is a point of production or sales amount to be done so the cost can be covered again or the value where the profit received by UKM is zero.

$$
\begin{aligned}
B E P \text { unit }=\frac{F C}{P-V C} \quad & \text { Or } B E P \text { rupiah }=\frac{F C}{1-V C / P} \\
\text { Where }: \mathrm{FC} & =\text { Fixed Cost } \\
\mathrm{P} & =\text { Selling price per unit } \\
\mathrm{VC} & =\text { Variable Cost per unit }
\end{aligned}
$$

\section{Legal Aspects}

Evaluation on the legal aspects needs to be done, for business owners. This evaluation is very useful for surviving the business as well as in order to convince the investors to take part in a business and does not deviate from the applicable rules. In a business, where is many interested parties can join, violation could be happened among each party, so enforcement of the rules becomes important to be implemented. Evaluation undertaken includes the form of business to use, the guarantees that could be given if someone want ask for a loan, as well as deeds, certificates and permits required in running the business

\section{Environmental Aspects}

Growth and development of the company can not be separated from the surrounding. This environment can have a positive or negative impact to company, so in the feasibility study this aspect also needs to be analyzed. Environmental factors are not static but dynamic. For example, at this time a certain condition have a positive effect for the company, in the future it could be a negative effect, and vice versa, so if someone feasibility study maker is required to be an observant in analyzing the dynamics of this environment.

\section{B. Bran}

Bran is a brown layer of rice husk, which is made up from several layers, namely: pericarp, seed coat, nucleus and aleurone. Bran has a high nutrient ingredient. Nutrient content found in rice bran is protein, fat, carbohydrate, dietary fiber, various vitamins, minerals and also phytochemicals. Bran contains $25.3 \mathrm{gr} / 100 \mathrm{gr}$ of food fiber consisting of cellulose, hemicellulose and pentosan which are insoluble fiber in water. The fiber content of rice bran is high and able to help fulfill the requirement of Indonesian population fiber recommended by AKG 2013 for $38 \mathrm{gr} /$ day so it is very good for use as fiber source.

Bran is one of the side product of rice milling process, besides bran is a healthy food contains antioxidants, multivitamins and high fiber to prevent degenerative diseases and also rich in starch, protein, fat, vitamins and minerals [10].

Bran has a higher fiber than rice [11]. Bran is a by-product of processing of rice or grain formed from the outer layer of brown rice in the milling to produce white rice or rice head. Rice mill produces about $60-65 \%$ of rice and bran around 8$12 \%$. Bran contains a relatively high protein of $11.3-14.9 \%$, dietary fiber content of 7.0-11.4\% and rich in vitamin B1 (11.1$12.9 \mathrm{mg} / 100 \mathrm{~g})$ and vitamin E (1, 9-2.9 mg / $100 \mathrm{~g})$, free fatty acid 2.8-4.1\% and minerals. Bran is also a food that is hypoallergenic and is a good source of dietary fiber (dietary fiber) [12]. Stages in the manufacture of bran flour, as follow:

1. Grinding process: This rice braning process aims to reduce the size of the material to pass in 80 mesh.

2. Roasting: Roasting done within 3-7 minutes at a temperature of approximately $70-90^{\circ} \mathrm{C}$. This filtering aims to activate the enzyme contained in fresh bran. In addition, the banana penyangraian process is done by adding pandan leaves to improve the flavor and to cover the typical smell of bran.

3. Sifting: Sifting is done using mesh 80, so that bran is obtained in accordance with the wishes and not too rough.

\section{RESEARCH METHOD}

\section{A. Data collection}

The data used in this research were a primary data and secondary data. Primary data is data obtained from interviews, questionnaires and direct observation in the field. While the secondary data are obtained from the results of company reports, articles, and institutional data associated with this research. Data collection can be done by using two research methods, Quantitative and Qualitative Methods. Quantitative data and information that has been obtained is processed by using Microsoft Excel, and presented in tabulation form to classify and facilitate in analyzing data. Quantitative data include cost data both investment cost, as well as operational cost and income data as a result of the sale of healthy rice bran chicken noodle products. For qualitative data such as market aspect analysis, technical aspects, management aspects, legal 
aspects and environmental aspects will be presented in the form of descriptive analysis.

\section{B. Equations}

The Rice bran chicken noodle is a kind of culinary business. Feasibility study conducted on the evaluation of the healthy rice bran chicken noodle as a consideration for owner to running the business in the future. In addition, the feasibility study is als o conducted to determine whether the plans and strategies that have been done for this culinary business has been well structured. In general, this feasibility study aims to determine whether the Rice bran chicken noodle is feasible to be implemented.

Research steps need to be done systematically to the direction and purpose of the research does not deviate from the problems that have been formulated at the beginning of the study. In this research, some steps were done by doing initial observation, problem identification, literature study, data collection, processing and data analysis then draw conclusion and suggestion. The feasibility study conducted to analyze non financial aspect, financial aspect, and sensitivity level effort against changes. Below is a flowchart of research stages:

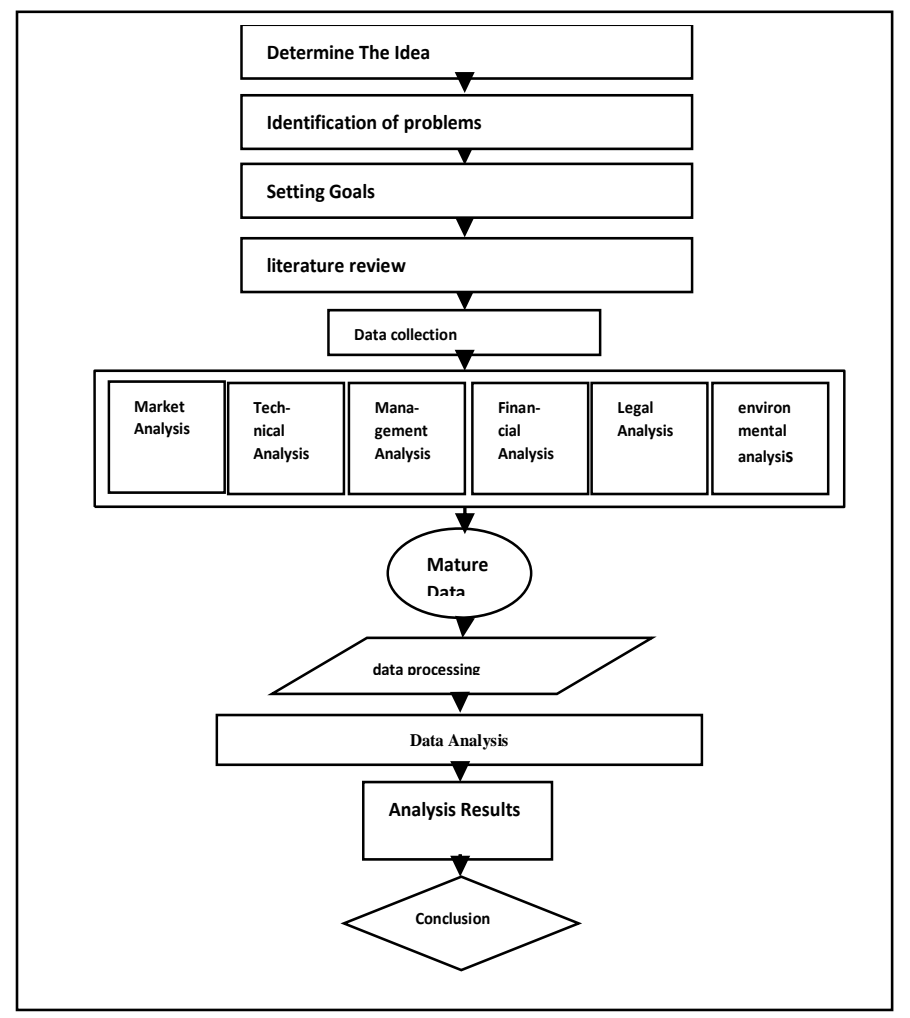

Fig. 1. Stages of Research

\section{RESULT AND DISCUSSION}

The results of the feasibility study of the establishment of rice bran chicken noodle stall starting from the market aspect, technical aspects, management aspects, financial aspects, legal aspects and environmental aspects as follows.

\section{A. Market Aspects}

\section{Segmentation, Targeting and Positioning}

a. Segmentation: The segmented marked for Healthy Rice Bran Chicken Noodle product is geographical segment, in Situbondo, from middle to lower class with various age range located in Asem Bagus.

b. Targeting: target market selected for Healthy Rice Bran Chicken Noodle product is a local resident nearby.

c. Positioning: Presentation of Healthy Rice Bran Chicken Noodle is sold in the form of food stalls served warmly in accordance with the wishes of customers. Noodle were cooked by the owner without the use of preservatives, so it is safe to be consumed by people, from children to adults. Thus the business strategy that will be the author established that can provide more value than other competitors and get a distinctive position in the hearts of customers.

\section{Sales Plan and Market Share}

The sales plan in the first year targeted to reach 10,500 portions per month. Then in the second year the production capacity is increased to 11,250 portions every month and in the third year it is targeted to reach 12,000 portions per month. Increased production capacity and sales plan is done by increasing the production workforce.

\section{Corporate Marketing Strategy Against Competitors}

a. Product: The product in this research is referred in the form of tangible goods that is Mie Ayam products made from raw bran mixture and natural ingredients that are nutritious and healthy.

b. Price: The price is based on the costs incurred to meet the used of raw materials in accordance with the prevailing market price and the expected profit. In determining the amount of price to be offered to consumers, then Mie Ayam Bekatul pricw will price Rp.6.000 / portion.

c. Promotion: As a new business activity started by Mie Ayam Bekatul still many people who do not know what is the product about. This condition requires promotional activities as a way out to introduce products offered by the owner. Many ways can be done as a media campaign, such as promotion to consumers by providing flyers (brochures) to visitors, workers and employees who work around the Mie Ayam stall or the wider community who provide information on new products at Kedai Mie Ayam as well as installation of banners near the sales location to be seen by visitors.

d. Place: A healthy rice bran chicken noodle is a direct selling business. The business location choice will be very decisive on direct sales. Located in Kampung Market which is precisely close on Jl. Raya Asem Bagus, is a strategic location, It is expected that the selection of direct location is easy to reach the 
visitors when they were passing around pantura which is close to the nice spot in Situbondo, such as Alun-Alun Plaza.

\section{B. TechnicalAspects}

Analysis on this aspect is done to find out whether the business of healthy rice bran chicken noodle is feasible to run effectively. The things to consider on the technical aspects will be discussed in this research include several things:

\section{Site Selection}

Determine a correct position is very important for the business establishment. There are several reasons to be considered in choosing the location for business establishment. The choice of location of a business can be based on the proximity of the business location with the source of raw materials, the proximity of the business location to the workforce, or the proximity of the business location with the consumer. In the case of healthy rice bran chicken noodle the selected location is based on the proximity of the location with the consumer. This is chosen because the business of healthy rice bran chicken noodle is a business that makes direct sales (direct selling).

The selected is nearby the market area of Kampung Market in Jl. Raya Asem Bagus. This location is a strategic, located on the border on Daendels road (SitubondoBanyuangi) with a quite crowded area plus 500 meters from the location is the famous Asem Bagus square (the second city of Situbondo), a place for young people in Situbondo to

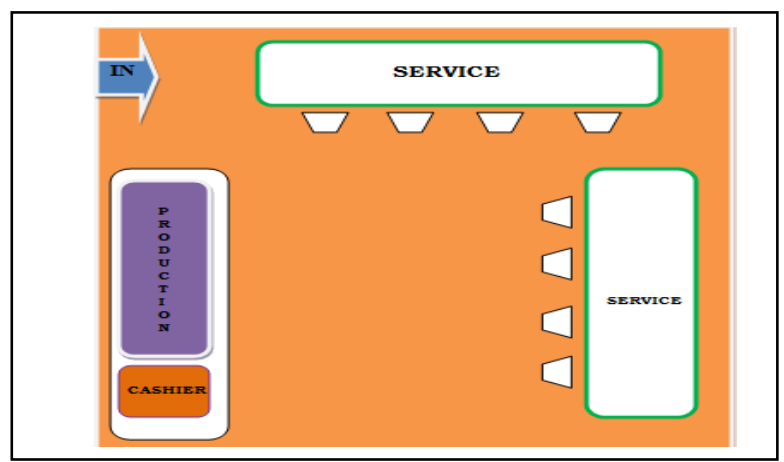

hang out

Fig. 2. Layout of rice bran noodle shop

\section{Layout}

Healthy Rice Bran Chicken noodle shop is separated the production and sales place and still belonging to the street vendor styles, so its only able to accommodate around 10 consumers at once. The food stall consists of rombong, table and chairs. For more details form sales layout rice bran chicken noodle can be seen below.

\section{Production Process and Technological Features}

Process of production conducted by healthy rice bran chicken noodle is focused on the production of the main ingredients or complementary materials for the final product later. The materials produced in the form of healthy rice bran noodle. Complementary materials produced in the form of crackers and spices typical of chicken noodles. All raw materials are imported directly produced every day (once time) to serve a fresh noodle all the time.
The technology that has been utilized in the production process of this rice bran is to use a roll machine to compress the dough noodles at once using a machine roller noodle powered $200 \mathrm{~W}$ with capable of producing $25 \mathrm{Kg}$ noodle within 30 minutes, for more details can be seen in the picture below.

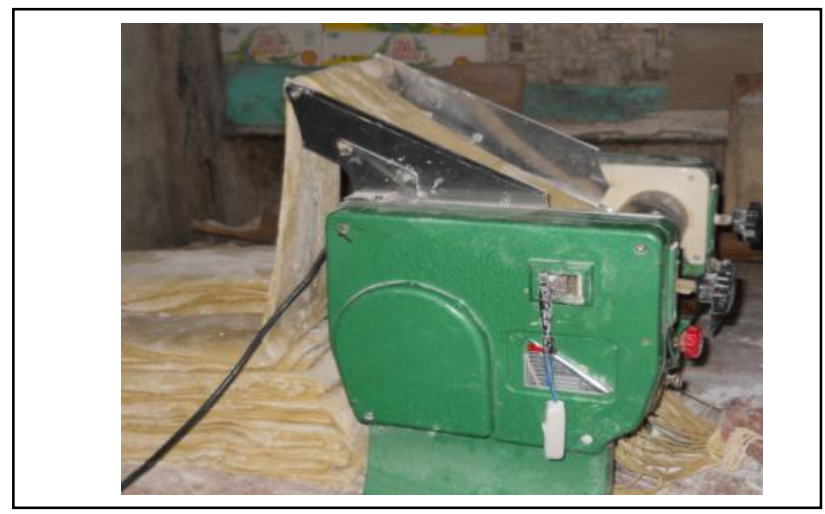

Fig. 3. Rool Machine and Noodle Printer

\section{Raw Materials and auxiliary materials}

Raw materials used in the process of making healthy rice bran noodle is composed of main ingredients and auxiliary materials, for the main ingredients of noodles are: Rice Bran Flour, starch, Wheat Flour, Food Colori, Soda cake. For the complete ingredients: Chicken, Spinach, tomato sauce, Chilli sauce, Soy sauce, Edible Oil, Sugar, Salt, Pepper, Red Onion, Garlic, Flavoring, etc. All the raw materials of production are obtained easily in the market except the rice bran. The rice bran flour is still hardly found in Situbondo, so it must taken from Central Java.

\section{Production Personnel}

This healthy rice bran chicken noodle is a small business. The members who run the business is 3 people, included supervisors, production and sales.

\section{Machinery and Equipment}

Equipment used for the production of healthy rice bran chicken noodle is varied from start to finish process, as for the equipment used as follows: scales, wok, noodle incense, various serok, scales, stove jos, blander, bowl, spoon, fork, chopsticks, knives, and other kitchen utensils. For machines used in the form of blander machine and roll machine.

\section{Land, Building and Equipment}

Place of production and place of healthy rice bran chicken noodles that become the object of research is not in one place, to place its production is 100 meter from place of sale precis ely in house owner (owner) of noodle shop. For the place of sale is on the roadside in front of the village market (Jl Raya Asem Bagus, Situbondo) by paying 6000 rupiah per day .

\section{Sales Process}

The process of selling in this business is the process of raw materials produced from the production process to arrive at the consumer. Hours of sale operation in this healthy rice bran chicken noodle shop is at 17.00. - 23.00 pm every day. Inside this sale location, owners and workers. 


\section{Management Aspects}

Culinary business of healthy rice bran chicken noodle is a small business that does not require formal organizational structure like a public company. Although without a complete organizational structure, this culinary business has a clear job description, so the production and sales process can runs every day. For more details division of the task can be seen in the picture below.

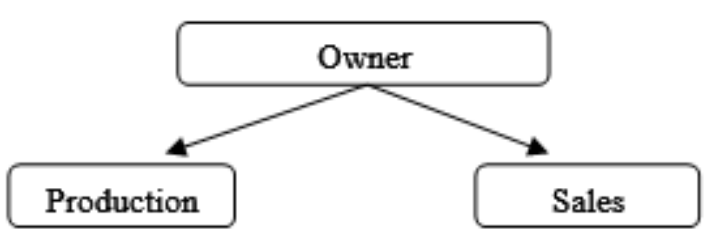

Fig. 4. Organizational Structure Healthy Rice Bran Noodle

\section{Owner's job}

- Responsible for production and sales processes to continue

- Supervision from beginning to end of noodle production to conform to established standards

Production

- Preparing raw materials

- Making noodles from initial to half-finished

Sales

- Serving customers

- Prepare the ingredients of hinga chicken ready noodles

- Act as a cashier

\section{Legal Aspects}

Analysis in this aspect of law is intended to find out whether a business is believed to be worth seeing in terms of legality. On the legal aspect, things that need to be analyzed is the form of business entity that is run and business permission obtained for this culinary business. Healthy rice bran noodle business is included in the type of micro small and medium enterprises. This business is also included in the form of a sole proprietorship whose entire capital is borne entirely by the business owner.

This Rice Bran Chicken Noodle is included in the type of small business that has criteria of net worth of maximum Rp. $200,000,000$ and have annual sales maximum 1.000.000.000. The field is currently on the culinary field. This must have legal legality, which is legalized by the local government nearby the business site. The permission given by of the local government is for s certain period, and need to be extended even this food stall still classified as street vendors. But later, if the owner want to expand his business and increase the number of production capacity it must equip with legal permit form established by the local government.

\section{E. Environmental Aspects}

In some businesses the environmental aspect is the most important aspect to be analyzed, usually on businesses that may produce hazardous waste to the surrounding. This Rice bran chicken noodle does not produce any hazardous wastes such as chemicals and others. Its produces organic wastewater which generated as well as household wastes in general, such as leather spices, vegetable remains, paper wrap, etc. Waste generated from the cleaning and processing of materials is discharged through available sewers, while solid waste from the production process will be collected in trash then disposed to the public garbage dump every day. There is also waste that can not be recycled like a sack from the remaining raw material. To process this, usually the owner collected them into one pack and send it to the recycling plant.

\section{F. Financial Aspects}

The analysis of financial aspects is considered as the most important aspect in the establishment of a business. Basically in doing a business improvement is needed from the financial aspect. The financial aspect analysis on this chicken noodle product consists of planning, physical plan, cost budget plan, revenue plan, and investment criteria analys is .

\section{Fund Needs}

The cost for running this business consists of investment capital requirements and working capital needs. The need of investment consists of the cost of building lease for one year and the cost for the fulfillment of equipment and equipment for production needs. Total of investment is Rp. 139,449,000. It can be seen in detail in Tablel I.

TABLE I. INVESTMENT FUND BUSINESS RICE BRAN NOODLE

\begin{tabular}{|c|l|c|c|r|r|}
\hline No & Item & Units & Total & Price (Rp) & $\begin{array}{c}\text { Total Price } \\
(\mathbf{R p})\end{array}$ \\
\hline 1 & Shop & Piece & 1 & $8,000,000$ & \multicolumn{1}{c|}{$8,000,000$} \\
\hline 2 & Building & Rupiah & 1 & $105,000,000$ & $105,000,000$ \\
\hline 3 & motorcycle & Rupiah & 1 & $15,000,000$ & $15,000,000$ \\
\hline 4 & Lounger & Piece & 2 & 500,000 & $1,000,000$ \\
\hline 5 & Table & Piece & 1 & 600,000 & 600,000 \\
\hline 6 & Refrigerator & Piece & 1 & $1,500,000$ & $1,500,000$ \\
\hline 7 & $\begin{array}{l}\text { Production } \\
\text { machine }\end{array}$ & Piece & 2 & 900,000 & $1,800,000$ \\
\hline 8 & LPGstoves & Piece & 1 & 350,000 & 350,000 \\
\hline 9 & Stove jos & Piece & 1 & 200,000 & 200,000 \\
\hline 10 & $\begin{array}{l}\text { Gas } \\
\text { cylinders }\end{array}$ & Piece & 3 & 300,000 & 900,000 \\
\hline 11 & Pan & Piece & 1 & 200,000 & 200,000 \\
\hline 12 & Pan & Piece & 2 & 200,000 & 400,000 \\
\hline 13 & Blender & Piece & 1 & 350,000 & 350,000 \\
\hline 14 & Noodle box & Piece & 2 & 200,000 & 400,000 \\
\hline 15 & sceles & Piece & 1 & 150,000 & 150,000 \\
\hline 16 & $\begin{array}{l}\text { Table } \\
\text { genjot }\end{array}$ & Piece & 1 & $1,000,000$ & $1,000,000$ \\
\hline 17 & $\begin{array}{l}\text { Vegeteble } \\
\text { sudip }\end{array}$ & Piece & 3 & 35,000 & 105,000 \\
\hline 18 & Knife & Piece & 5 & 50,000 & 250,000 \\
\hline 19 & Fork & Dozen & 3 & 45,000 & 135,000 \\
\hline 20 & Spoon & Dozen & 3 & 40,000 & 120,000 \\
\hline 21 & Bowl & Dozen & 3 & 150,000 & 450,000 \\
\hline 22 & Filter & Piece & 1 & 39,000 & 39,000 \\
\hline 23 & $\begin{array}{l}\text { Kitchen } \\
\text { equipment }\end{array}$ & Dozen & 1 & $1,500,000$ & $1,500,000$ \\
\hline & Total & & & $139,449,000$ \\
\hline
\end{tabular}

The need of working capital consists of the fulfillment of costs for raw materials, the cost for packaging needs, labor costs, and other expenses. Total requirement of working capital cost is $\mathrm{Rp}$ 1.454.000. The working capital requirement is the 
working capital for the company's weekly activities in the first year of operation.

TABLE II. WORKING CAPITAL BUSINESS OF RICE BRAN NOODLES

\begin{tabular}{|c|c|c|c|c|c|c|c|}
\hline No & Item & Units & Total & Pricea $(\mathbf{R p})$ & Total Price (Rp) & $\begin{array}{l}\text { Cost per } \\
\text { Month } \\
\text { (Rp) }\end{array}$ & $\begin{array}{l}\text { Cost Per } \\
\text { Year Rp) }\end{array}$ \\
\hline $\mathrm{A}$ & Raw material & & & & & & \\
\hline 1 & Rice Bran & $\mathrm{kg}$ & 2 & 84,000 & 168,000 & $4,200,000$ & $50,400,000$ \\
\hline 2 & Starch & $\mathrm{kg}$ & 5 & 9,000 & 45,000 & $1,125,000$ & $13,500,000$ \\
\hline 3 & Wheat flour & $\mathrm{kg}$ & 25 & $\begin{array}{l}7,000 \\
\end{array}$ & 175,000 & $4,375,000$ & $52,500,000$ \\
\hline 4 & Chicken meat & $\mathrm{kg}$ & 8 & 30,000 & 240,000 & $6,000,000$ & $72,000,000$ \\
\hline \multicolumn{5}{|c|}{ Total Value of Raw Materials } & 628,000 & $15,700,000$ & $188,400,000$ \\
\hline B & $\begin{array}{l}\text { Supplementary } \\
\text { material }\end{array}$ & & & & & & \\
\hline 1 & tomato sauce & bottle & 3 & 15,000 & 45,000 & $1,125,000$ & $13,500,000$ \\
\hline 2 & $\begin{array}{l}\begin{array}{l}\text { Vegetable } \\
\text { mustard }\end{array} \\
\text { mats }\end{array}$ & $\mathrm{kg}$ & 5 & 5,000 & 25,000 & 625,000 & $7,500,000$ \\
\hline 3 & Teek & $\mathrm{kg}$ & 2 & 12,000 & 24,000 & 600,000 & $7,200,000$ \\
\hline 4 & saos lombok & bottle & 3 & 15,000 & 45,000 & $1,125,000$ & $13,500,000$ \\
\hline 5 & Soy sauce & bottle & 5 & 15,000 & 75,000 & $1,875,000$ & $22,500,000$ \\
\hline 6 & salty soy sauce & bottle & 1 & 10,000 & $\begin{array}{ll}10,000 \\
\end{array}$ & 250,000 & $3,000,000$ \\
\hline 7 & Cooking oil & liter & 5 & 15,000 & 75,000 & $1,875,000$ & $22,500,000$ \\
\hline 8 & baking soda & $\mathrm{kg}$ & 1 & 42,000 & 42,000 & $1,050,000$ & $12,600,000$ \\
\hline 9 & sugar & $\mathrm{kg}$ & 3 & 13,000 & 39,000 & 975,000 & $11,700,000$ \\
\hline 10 & Salt & wrap & 3 & 11,000 & 33,000 & 825,000 & $9,900,000$ \\
\hline 11 & Food coloring & bottle & 1 & 15,000 & 15,000 & 375,000 & $4,500,000$ \\
\hline 12 & Pepper & $\mathrm{kg}$ & 0.5 & 200,000 & 100,000 & $2,500,000$ & $30,000,000$ \\
\hline 13 & Red onion & $\mathrm{kg}$ & 2 & 32,000 & 64,000 & $1,600,000$ & $19,200,000$ \\
\hline 14 & Garlic & $\mathrm{kg}$ & 2 & 40,000 & 80,000 & $2,000,000$ & $24,000,000$ \\
\hline 15 & Vinegar & bottle & 1 & 5,000 & 5,000 & 125,000 & $1,500,000$ \\
\hline \multicolumn{5}{|c|}{ Total Price of Complementary Materials } & 677,000 & $16,925,000$ & $203,100,000$ \\
\hline $\mathrm{C}$ & Packaging & & & & & & \\
\hline 1 & Plastic packagng & pack & 10 & 8000 & 80,000 & $2,000,000$ & $24,000,000$ \\
\hline 2 & Plastic spoon & Dozen & 10 & 500 & 5,000 & 125,000 & $1,500,000$ \\
\hline 3 & $\begin{array}{l}\text { Food wrapping } \\
\text { non }\end{array}$ & pack & 8 & 8000 & 64,000 & $1,600,000$ & $19,200,000$ \\
\hline \multicolumn{5}{|c|}{ Total Prices Package materials } & 149,000 & $3,725,000$ & $44,700,000$ \\
\hline \multicolumn{5}{|c|}{ Total } & $1,454,000$ & $36,350,000$ & $436,200,000$ \\
\hline
\end{tabular}

Fulfillment of the funds needed in the business of healthy rice bran chicken noodle is obtained entirely from the capital itself ie from the direct business owner..

\section{Physical Needs Plan}

Physical needs plan on this healthy rice bran chicken noodle business is a planning about the physical needs required by this business during the period of business. Analys is of this physical needs plan is done to know every physical needs in supporting business activities in detail in the business period every year. This physical need consists of building production, production equipment and equipment, raw materials production, energy and labor.

Equipment and supplies of rice bran chicken noodle production consists of various cooking and supporting equipment in accordance with the stages of production such as stoves, refrigerators, dandang, wok, and so forth. The need for raw materials consists of ingredients such as noodles, chicken meat, vegetable mustard, spring onion, and various other complementary materials. Energy requirements used are electrical energy and LPG gas used in lighting for electricity and cooking purposes for LPG gas. The need for labor is fulfilled by 5 laborers who work together as labor production and sales force.

\section{Budget Plan}

The cost budget plan is the sum of all the costs required in the rice bran chicken noodle business. In general, this budget cost plan is the amount of costs required to meet the physical needs previously described.

Costs included in the cost budget plan consist of building costs obtained by leasing the store yard by Rp. 60,000 for one month, equipment and equipment cost of Rp 139,449,000, production cost and material cost of $R p 36,350,000$, labor cost consisting of wages, allowances and consumption of $\mathrm{Rp}$ 300,000 , and other expenses comprising of electricity, water, transport and gas needs of $\mathrm{Rp} \mathrm{1,685,000.}$

TABLE III. T ABLE STYLES SUMMARY OF BUDGET PLAN OF RICE BRAN NODLE COST

\begin{tabular}{|l|lr|}
\hline \multicolumn{1}{|c|}{ Item } & \multicolumn{2}{|c|}{ Budget Plan (Rp) } \\
\hline Building Rent & $\mathrm{Rp} \quad 60.000$ \\
\hline Equipment and Production Equipment & $\mathrm{Rp} 139.449 .000$ \\
\hline Raw Material Production and Equipment & $\mathrm{Rp}$ & 36.350 .000 \\
\hline Labor Cost & $\mathrm{Rp} \quad 300.000$ \\
\hline Other Cost & $\mathrm{Rp} \quad 1.685 .000$ \\
\hline
\end{tabular}

\section{Evaluation of Profit Loss Calculation}

Evaluation on this research cover on profit and loss of business planning during a year when this business started. The results of the calculation is very crucial, because it become a consideration whether this business can run properly or not. Overall in the first year can generate sales profit of $\mathrm{Rp}$ $86,982,000$. For more complete calculation of profit and loss in the first year until the estimated fifth year can be seen in Table IV.

TABLE IV. PROFIT AND LOSS CALCULATION

\begin{tabular}{|c|l|r|r|r|r|}
\hline \multirow{2}{*}{ No } & \multirow{2}{*}{ Description } & \multicolumn{4}{|c|}{ Year of Analysis } \\
\cline { 3 - 6 } & & $\mathbf{0}$ & $\mathbf{1}$ & \multicolumn{1}{c|}{$\mathbf{2}$} & \multicolumn{1}{c|}{$\mathbf{3}$} \\
\hline A & Inflow & & $585,000,000$ & $564,000,000$ & $573,600,000$ \\
\hline B & Outflow & & & & \\
\hline & 1. Investment Cost & $139,449,000$ & & & \\
\hline & 2. Fixed Costs & & $24,540,000$ & $24,540,000$ & $24,540,000$ \\
\hline & 3. Variable Cost & & $436,200,000$ & $435,000,000$ & $436,800,000$ \\
\hline & Total Outflow & $139,449,000$ & $460,740,000$ & $459,540,000$ & $461,340,000$ \\
\hline C & Benefit (A-B) & $(139,449,000)$ & $124,260,000$ & $104,460,000$ & $112,260,000$ \\
\hline D & Income tax (30\%) & & $37,278,000$ & $31,338,000$ & $33,678,000$ \\
\hline E & Net Benefit & $(139,449,000)$ & $86,982,000$ & $73,122,000$ & $78,582,000$ \\
\hline F & Discount Factor $15 \%$ & & 0.8696 & 0.7561 & 0.6575 \\
\hline G & PV/year & $(139,449,000)$ & $75,639,547$ & $55,287,544$ & $51,667,665$ \\
\hline H & PV positive & $277,332,658$ & & & \\
\hline I & PV negative & $(139,449,000)$ & & & \\
\hline J & NPV & $137,883,346$ & & & \\
\hline K & Net B/C & 2.01 & & & \\
\hline L & IRR & $45 \%$ & & & \\
\hline M & Pay backPeriod & 1.6 & & & \\
\hline N & BEP & & $32,911,279$ & $31,817,379$ & $32,225,604$ \\
\hline
\end{tabular}

\section{Investment Feasibility Analysis}

In this research, financial feasibility analysis to determine the feasibility of business. Financial feasibility analysis conducted to determine whether with the addition of new products, is still feasible or not to operate. The financial 
feasibility analysis of healthy rice bran chicken noodle business consists of estimation of production capital.

Analysis of investment criteria aims to determine the feasibility of a business when viewed from the financial aspect. The feasibility can be seen through five analysis of investment criteria, namely Net Present Value (NPV), Internal Rate of Return (IRR), Net Benefit-Cost Ratio (Net B / C), Break Event Point (BEP), and Payback Period (PBP). The value of the analysis result of the investment valuation criteria can be seen in Table V.

TABLE V. VALUE OF ASSESSMENT CRITERIA INVESTMENT OF RICE BRAN NOODLES

\begin{tabular}{|l|l|}
\hline Kriteria Investasi & Nilai \\
\hline Net Present Value (NPV) & $\mathrm{Rp} 137.883 .346$ \\
\hline Internal Rate of Return (IRR) & $45 \%$ \\
\hline Net Benefit-Cost Ratio (Net B/C) & 2,01 \\
\hline BreakEvent Point (BEP) (Tahun Pertama) & $\mathrm{Rp} 32.911 .279$ \\
\hline Payback Period (PBP) & 1,6 Tahun \\
\hline
\end{tabular}

a. Net Present Value (NPV)

The value of NPV on this rice bran chicken noodle is Rp $137,883,346$. It indicates the amount of profit to be gained by rice bran chicken noodles during the 5 year analysis period based on the current value when its assessed with the interest rate of $15 \%$. The value of NPV shows that the business is feasible to run because it qualifies the NPV value to be greater than zero.

\section{b. Internal Rate of Return (IRR)}

feasibility of a business can be seen if it has an IRR value greater than the interest rate applied. The IRR value in this rice bran chicken noodle business is $45 \%$. The value is greater than the interest rate used is $15 \%$ so that the business is feasible to run. IRR value contained on rice bran chicken noodle can be categorized as high. The high value of IRR is due to the investment cost which tend to be small because this business get its place of business by way of rent.

\section{c. Net Benefit - Cost Ratio (Net B/C)}

Net B / C is the value of the ability of a business to generate profit in each unit of investment issued. The Net B / C value obtained is 2.01 . The value indicates that from every Rp. 1 value of investments issued from this business may result in a net benefit of Rp.86,982,000. One of the requirements of business feasibility it must have a Net B / C value greater than one, then this business is feasible to run because it has a value of 2.01 which shows greater than one.

\section{d. Break Event Point (BEP)}

BEP is the value of a situation where the business is experiencing a breakeven point that is not experiencing losses and profits. BEP value in the first year is amounted to Rp 32.911.279, these values indicate it must make a minimum sale of Rp $585,000,000$, to reach its breakeven point or not to lose. The BEP value of this business for the second year is Rp31.817.379 and the third year is Rp 32.225.604.

\section{e. Payback Period (PBP)}

Payback period can be interpreted as the period needed as effort to return the amount of investment issued at the beginning of the business period. This bbusiness could get a payback period of 1.6 years or for 1 year 7 months and 6 days. This means that the business has been able to cover its investment value at 1,6 years and half.

\section{CONCLUSION}

Based on the results of non-financial feasibility analysis on a market, technical, management, law and environment aspects, still not found any obstacles for the establishment of healthy rice bran Chicken Noodle, but the things have to concern is the technical aspects because the raw material for the product still imported from the outside. For the results of financial analysis in accordance with investment valuation criteria obtained Net Present Value (NPV) results of Rp. 137,883,346, Internal Rate of Return (IRR) of 45\%, Net Benefit-Cost Ratio (Net B / C) obtained 2.01, Break Even Point (BEP) of Rp. 32.911.279, and Payback Period (PP) is 1 year 7 months 6 days. In short, the establishment of Rice Brand Chicken Noodle Stall is feasible to be run and developed.

For anyone who are interest to start a similar business should pay attention to how to maintain the raw materials in the form of bran flour because the availability is still limited in certain areas. Beside the marketing strategy and the sale price of this product, things have to noticed is how to order to obtain profits comparable with the costs incurred and the time required in return of investment is not too long.

\section{REFERENCES}

[1] K Adom , Liu R. Antioxidant activity of grains. Journal of Agricultural and Food Chemistry. 2002;50:6182-6187.

[2] J Godber , Xu Z, Hegsted M, Walker T. Rice and rice bran oil in functional foods development. Louisiana Agriculture. 2002;45:9-10.I.S.

[3] C Rohrer, Siebenmorgen T. Nut raceutical concentrations within the bran of various rice kernel thickness fractions. Biosystems Engineering. 2004;88:453-460.

[4] A Gescher. "Evaluation of the cancer chemopreventive efficacy of rice bran in genetic mouse models of breast, prostate and intestinal carcinogenesis.," 2007 Jan 29;96(2):248-54.

[5] T Sugiharto, Sumiati. 2002. "Feasibility Study of Abaca Banana Plantation Development Project Using Analysis of Capital Budgeting", Journal of Economics and Business, Volume 7, Number. 3:145-150.

[6] Jumingan, Business Feasibility Study (Theory and Making of Feasibility Proposal), Jakarta: Bumi Aksara, 2014.

[7] K Syarif, Business Feasibility Analysis of Aromatic Oil Brand Flosh Products (A Case Study on UKM Marun Aromatherapy),Bogor: Bogor Agricultural University, 2011.

[8] S Evan, Feasibility Analysis of Milkfish Production Process at BANISI in Soreang, Bogor: Bogor Agricultural University, 2008.

[9] W Tirta, Wening K, I Kartika, Financial Feasibility Analysis of Local Commodity Production Business Development: Corn Based Noodle, Journal AGRITECH, Vol.34, No.2, Hal. 194-202, 2014.

[10] E Damayanthi . Rice Bran Stabilization and $\gamma$-Oryzanol Content of T wo Local Paddy Varieties "IR 64" and "Cisadane Muncul". Journal Technology and Food Industry. 2007;XV(1):11-9. 
[11] W Liandani, E Subaidah, formulation of instant noodles rice bran making, Journal of Food and Agro-industry, Vol. 3 No 1 p.174-185, Januari 2015.

[12] T Mulyani, SDjajati, L Dwi, Production of rice bran cookies (the study of rice bran - mocaf flour proportion ) with the margarine addition), Journal .REKAPANGAN, Vol.9, No.2, December 2015. 